\title{
Composition and origin of the aliphatic extractable hydrocarbons in the Puertollano (Spain) oil shale
}

\author{
J. C. del Rio, J. Garcia-Molla, F. J. Gonzalez-Vila and F. Martin \\ Instituto de Recursos Naturales y Agrobiologia de Sevilla, C.S.I.C., P. O. Box 1052 EP, 41080-Sevilla, \\ Spain
}

(Received 29 April 1992; returned for revision 16 June 1992; accepted 22 November 1993)

\begin{abstract}
The composition of the saturated aliphatic fraction extractable from the Puertollano oil shale, the most important deposit of this material in the Iberian Peninsula, has been studied by GC and GC-MS. This fraction contained mainly $n$-alkanes, $n$-alkylcyclohexanes, and $n$-alkylmethylcyclohexanes. The cyclohexanes showed a distribution very similar to that of $n$-alkanes suggesting a common origin. Contributions from higher plant derived material (mainly conifers) were apparent, based on the presence of diterpenoid compounds. An angiosperm contribution was evidenced by the presence of des-A-triterpenoid hydrocarbons, derived from oleanane and ursane skeletons. Hopanes, 8,14-secohopanes, ring-D aromatized 8,14-secohopanes, benzohopanes, a $C_{24}$ 17,21-secohopane and a $C_{31}$ hexacyclic saturated hopane were found in the extracts, showing the influence of microorganisms. Different pathways are suggested for the formation of benzohopanes, and the $C_{31}$ hexacyclic hopanoid found in the extracts.
\end{abstract}

Key words-Puertollano oil shale, biomarkers, 8,14-secohopanes, benzohopanes, terpanes, steranes

\section{INTRODUCTION}

The oil shale from Puertollano is the most important deposit of this type in the Iberian Peninsula. It forms part of a virtually undeformed intramontane basin of Late Stephanian age in the Southern part of $\mathbf{L a}$ Mancha (Central Spain) and contains both bituminous shales, and high volatile bituminous coals, in a generally lacustrine succession. Details on the geological settings of this deposit have been described by Wagner (1985). Seam B in the Calvo Sotelo Oil Shale Mine was the most important one commercially and was exploited for obtaining mineral oil by distillation during several decades; it was abandoned for economic reasons in 1964. Substantial reserves of oil shale remain, and these may become economic again when oil prices rise.

Despite intensive exploration activity in the Puertollano Basin, few geochemical studies have been reported in the literature. The first organic-geochemical studies of this deposit were exclusively centered on the physico-chemical characterization of the kerogen fraction (Robinson and Dineen, 1967; Robinson, 1969). A partial biomarker description, and some petrographic analysis of the Seam B of the Puertollano oil shale deposit, have recently been reported (Kruge and Suarez-Ruiz, 1991; Borrego et al., 1992; Blanco et al., 1992).

To achieve an organic-geochemical characterization of the Puertollano oil shale (POS) from an integrated point of view we are carrying out several studies. They include an inventory of aliphatic, aromatic and functionalized biomarkers, and the charac- terization of the kerogen by degradative and spectroscopic methods. This paper presents a study, by GC-MS, of aliphatic hydrocarbons in order to determine their origin and geochemical significance. Preliminary data on the composition and organicgeochemical significance of the aromatic fraction, and the kerogen, have already been described (Martín et al., 1991; del Río et al., 1993).

\section{MATERIALS AND METHODS}

The composite log of the stratigraphic succession in the Puertollano coal and oil shale field has been already described in Wagner (1985). Figure 1 shows the locale map of the Puertollano Basin in the Iberian Peninsula, and Fig. 2 shows the stratigraphic section of the lower part of the Puertollano succession as exposed in the (now abandoned) Calvo Sotelo Oil Shale Mine, in the central part of the Puertollano coal and oil shale field (around $\mathbf{4 0 0} \mathrm{m}$ subsurface). Mainly tuffaceous mudstones, one sandstone and two thin tuff bands have been found below the second oil shale horizon (Seam B) which is the one worked in the past by the Calvo Sotelo Mine (Fig. 2). Several thin tuff bands in this oil shale horizon apparently confirm the association with volcanic emissions. Well preserved fish remains occur in these bituminous shales, and particularly in the top part (Forey and Young, 1985). Drifted plant remains include conifer branches. Table 1 shows some important geochemical characteristics of the sample taken from the POS (Seam B) selected for this study. 
The ground and sieved sample $(50 \mathrm{~g})$ was exhaustively Soxhlet-extracted with toluene/methanol (3/1). The successive extracts were combined, and dried under reduced pressure. The extractable organic matter (EOM) was $9.6 \mathrm{mg} / \mathrm{g}$ rock. After removal of the asphaltenes by precipitation with $n$-pentane, the total saturated hydrocarbon fraction (with some monoaromatics) was isolated by adsorption chromatography on a column $(20 \times 1 \mathrm{~cm})$ of Florisil eluting exhaustively with $n$-hexane. The saturated fraction (3.1 mg sat./g rock) was further enriched in branched and cyclics by removing the $n$-alkanes with $5 \mathrm{~A}$ molecular sieve.

GC and GC-MS chromatographic analyses were carried out on Hewlett-Packard systems 5730A and 5988A respectively using fused silica capillary columns $(25 \mathrm{~m})$ coated with OV-101. $\mathrm{N}_{2}$ (GC) and $\mathrm{He}$ (GC-MS) at rates of $1 \mathrm{ml} / \mathrm{min}$ were used as carrier gases. The samples were injected in the splitless mode (1/60 split ratio and $2 \mathrm{ml} / \mathrm{min}$ septum purge) with a multiramp heating program: from 50 to $100^{\circ} \mathrm{C}$ at $32^{\circ} \mathrm{C} / \mathrm{min}$, and from 100 to $300^{\circ} \mathrm{C}$ at $6^{\circ} \mathrm{C} / \mathrm{min}$. The injector and detector were set at $300^{\circ} \mathrm{C}$. The identity of the compounds was determined by comparison of their mass spectra with those tabulated (EPA/NIH Mass Spectral Data Base), stored in computer libraries (NBS, Wiley) or previously published. Some homologous series were detected by single or multiple monitoring of diagnostic ions (SIM, MID). Quantitation of hydrocarbons was by peak area integration in the GC-FID traces using an external standard containing $n$-tetradecane, $n$-docosane and cholestane.

\section{RESULTS AND DISCUSSION}

Table 2 shows the different series of compounds detected in the saturated fraction of the POS, with an indication of the predominant components, and their relative abundances. The structures of each type of compounds (in Roman numbers throughout the text) are shown in the Appendix.

\section{Alkanes and alkylcyclohexanes}

The hydrocarbon fraction was characterized by a series of $n$-alkanes in the range $\mathrm{C}_{13}-\mathrm{C}_{35}$ as shown in Fig. 3. This series exhibited a very slight odd-overeven predominance, a maximum at $\mathrm{C}_{25}$ and a pre-

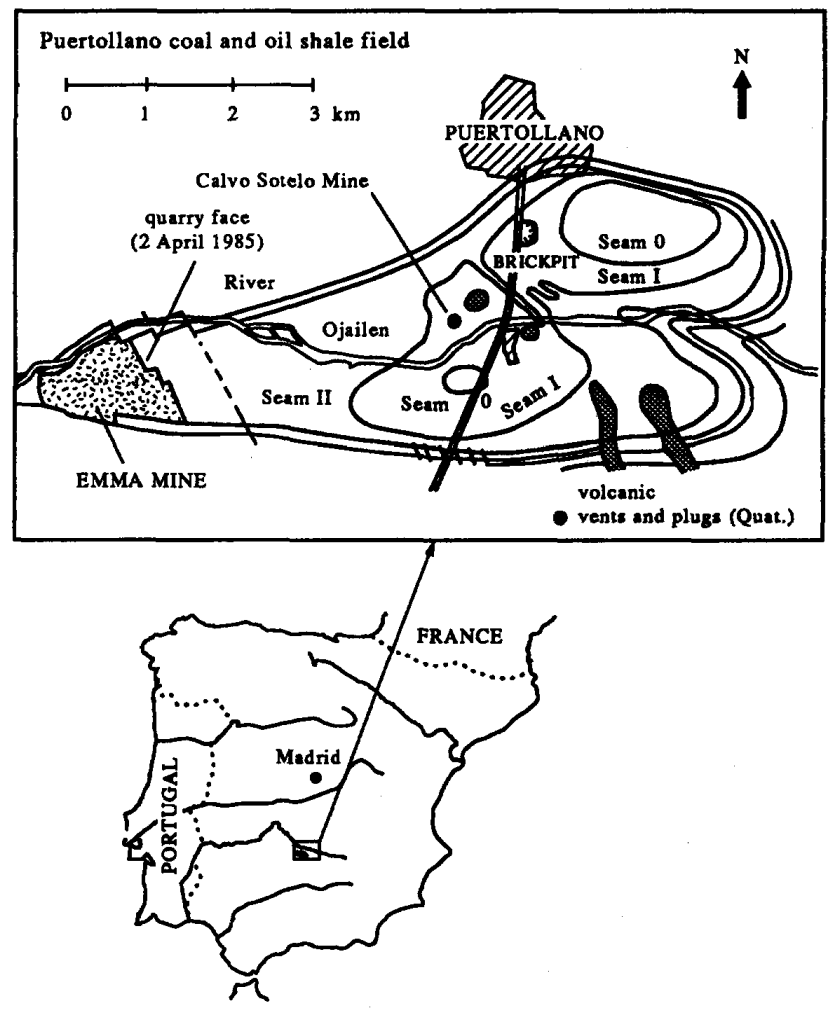

Fig. 1. Location map of the Puertollano Basin in the Iberian Peninsula, and position of the Calvo Sotelo Mine in the Puertollano coal- and oil-shale fietd. 


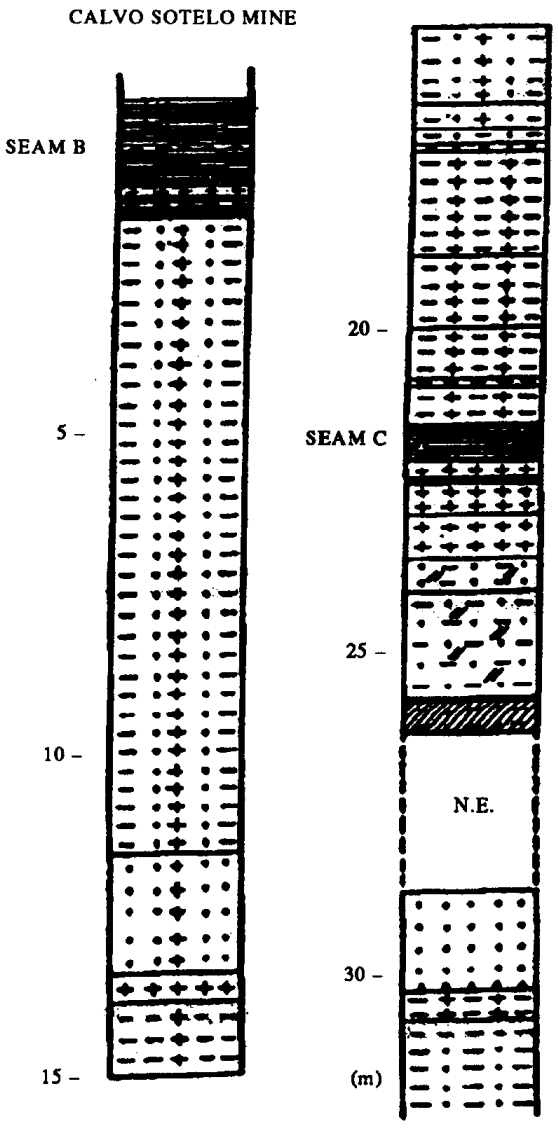

dominance of the $>\mathrm{C}_{23}$ homologs. Although the uniform $n$-alkane distribution does not allow a clear differentiation of different inputs, the lower homologs are interpreted to be derived from bacterial and/or algal debris whereas the biological sources for $n$ alkanes $>\mathrm{C}_{23}$, with the slight odd carbon number predominance, can be attributed to terrestrial plant waxes and/or algal lipids (Simoneit, 1978). Aliphatic acyclic isoprenoids, mainly phytane $\left(\mathrm{C}_{20}\right)$, pristane $\left(C_{19}\right)$, norpristane $\left(C_{18}\right)$ and farnesane $\left(C_{15}\right)$ were also encountered with a $\mathrm{Pr} / \mathrm{Ph}$ ratio of 2.8 .

Series of $n$-alkylcyclohexanes $\left(\mathrm{C}_{13}-\mathrm{C}_{28}\right)$ (I, Appendix 1) and $n$-alkylmethylcyclohexanes $\left(\mathrm{C}_{18}-\mathrm{C}_{28}\right)$ (II) were also found in the branched/cyclic fraction by monitoring the ions at $m / z 83$ and 97 respectively. Three different isomers, with methyl group in ortho-, meta- and para-positions were detected for the $n$ alkylmethylcyclohexane series. The distribution of the alkylcyclohexanes in the POS (shown in Fig. 4) is similar to that of the $n$-alkanes. This suggests a diagenetic relationship between the alkylcyclohexanes and the $n$-alkanes (or their likely precursors, the $n$-fatty acids). Ring closure of either the $n$-paraffins, or their precursors (e.g. fatty acids), has been suggested by several authors (Rubinstein and Strausz, 1979; Fowler et al., 1986).

\section{Terpenoid and steroid hydrocarbons}

Among the polycyclic hydrocarbons identified in the POS extracts were sesqui-, di- and triterpenoid and steroid hydrocarbons.

The partial chromatogram (Fig. 5) shows the trace of $m / z$ 123, which corresponds to the series of bicyclic sesquiterpanes $\left(\mathrm{C}_{14}-\mathrm{C}_{16}\right)$ detected in the extracts. The different structures were determined by comparison of their mass spectra with those previously reported (Alexander et al., 1984; Philp, 1985; Weston et al., 1989). The predominant homologues were $8 \beta(\mathrm{H})$-drimane (III, $\mathbf{R}=\mathrm{CH}_{3}$ ) and $8 \beta(\mathrm{H})$-homodrimane (III, $\mathrm{R}=\mathrm{C}_{2} \mathrm{H}_{5}$ ) with small amounts of other isomers. Alexander et al. (1984), suggested that drimane type compounds are probably formed by biological alteration of hopanoid precursors during diagenesis. In fact, the $8 \beta(\mathrm{H})$-drimane and $8 \beta(\mathrm{H})$-homodrimane have both structural and steric similarities to the $A / B$

Table 1. Some geochemical parameters of the Puertollano oil shale

\begin{tabular}{lr}
\hline Proximate analysis (\%) & \\
Moisture & 0.64 \\
Volatiles & 19.75 \\
Fixed carbon & 8.85 \\
Ash & 70.76 \\
Elemental analysis* (\%) & \\
$\mathrm{C}$ & 70.25 \\
$\mathrm{H}$ & 8.98 \\
$\mathrm{~N}$ & 1.85 \\
$\mathrm{~S}$ & 4.30 \\
O† & 14.62 \\
Vitrinite reflectance (\%) & 0.40 \\
Extractable organic matter (mg/g rock) & 9.60 \\
Saturates (mg/g rock) & 3.10 \\
\hline
\end{tabular}

Fig. 2. Stratigraphic succession of the lower part of the Puertollano Basin at the Calvo Sotelo Mine.

*Dry, ash-free.

†By difference. 
Table 2. Main series of compounds detected in the saturated fraction of extracted bitumen

\begin{tabular}{|c|c|c|c|c|}
\hline Series & Range & $\begin{array}{c}\text { Main } \\
\text { component }\end{array}$ & $\% 0^{*}$ & Structure $†$ \\
\hline $\begin{array}{l}n \text {-Alkanes } \\
\text { Acyclic isoprenoids } \\
n \text {-Alkylcyclohexanes } \\
n \text {-Alkylmethylcyclohexanes } \\
\text { Bicyclic terpanes } \\
\text { Diterpanes } \\
\text { Tricyclic terpanes } \\
\text { Tetracyclic terpanes } \\
\text { Tetracyclic } 17,21 \text {-secohopanes } \\
8,14 \text {-secohopanes } \\
\text { Ring-D aromatized } 8,14 \text {-secohopanes } \\
\text { Steranes } \\
\text { Pentacyclic hopanes } \\
\text { Benzohopanes } \\
\text { Hexacyclic hopanes }\end{array}$ & $\begin{array}{l}C_{13}-C_{35} \\
C_{15}-C_{20} \\
C_{13}-C_{28} \\
C_{13}-C_{28} \\
C_{14}-C_{16} \\
C_{19}-C_{20} \\
C_{19}-C_{28} \\
C_{24} \\
C_{24} \\
C_{27}-C_{30} \\
C_{27}-C_{31} \\
C_{27}-C_{29} \\
C_{27}-C_{35} \\
C_{32}-C_{35} \\
C_{31}\end{array}$ & $\begin{array}{l}C_{16} \\
C_{23} \\
C_{24} \\
C_{24} \\
C_{29} \\
C_{30} \\
C_{32} \\
C_{31}\end{array}$ & $\begin{array}{r}455 \\
75 \\
87 \\
87 \\
45 \\
40 \\
45 \\
10 \\
10 \\
6 \\
5 \\
10 \\
110 \\
10 \\
5\end{array}$ & 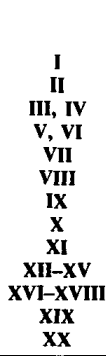 \\
\hline
\end{tabular}

-Relative abundances in the saturated fraction.

†Roman numbers refer to the structures shown in Appendix 1.

ring system of the hopanoids. The land plant derived 4B(H)-eudesmane (IV) (Philp and Gilbert, 1988a) and a $\mathrm{C}_{14}$ nordrimane hydrocarbon were also detected in minor amounts.

Three compounds with MW 262 corresponding to $\mathrm{C}_{19}$-tricyclanes were detected in the saturated fraction. The mass spectra of the two most prominent compounds corresponded to those reported by Philp (1985) for norabietane (V) and another isomer not yet identified. The third one is possibly a $\mathrm{C}_{19}$ tricyclic terpane. $\mathrm{A} \mathrm{C}_{20}$ diterpenoid, abietane (VI), was also found in the extracts. Some aromatic diterpenoids, such as simonellite, tetrahydroretene and retene were also found in the aromatic fraction and have already been described (del Río et al., 1993). Tricyclic diterpenoids are widespread in the plant kingdom, and are major constituents of conifer resins. Their presence in this sample therefore can be considered as an indication for the contribution of higher plant materials, mainly conifers, to the original organic matter (Philp and Gilbert, 1986b; Simoneit, 1986).

The partial $m / z 191$ mass fragmentogram (Fig. 6) shows the series of tricyclic terpenoid hydrocarbons $\left(\mathrm{C}_{19}-\mathrm{C}_{28}\right.$, VII) detected in the saturation fraction of the POS. The predominant member of this series was the $\mathrm{C}_{23}$ homologue, whereas the $\mathrm{C}_{22}$ and $\mathrm{C}_{27}$ members were present in very low relative proportions, as expected, due to the unfavourable loss of methyl

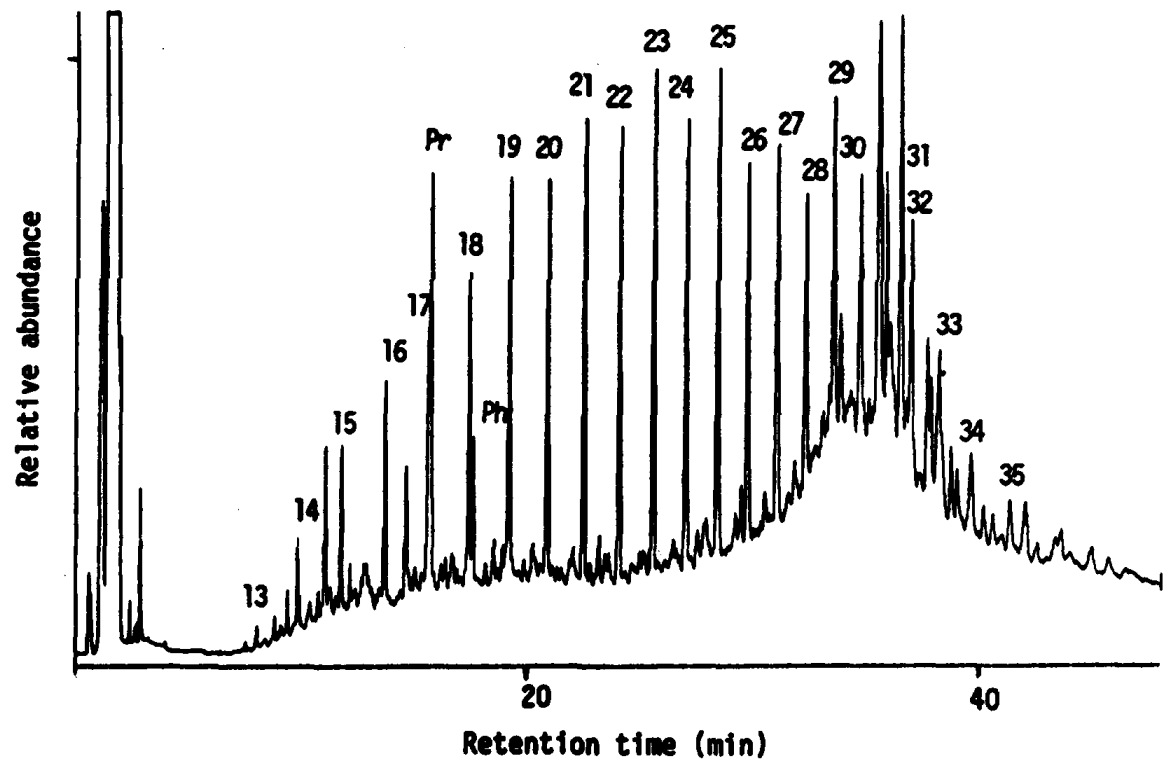

Fig. 3. Gas chromatogram (FID response) of the saturated fraction extracted from the Puertollano Oil Shale. 


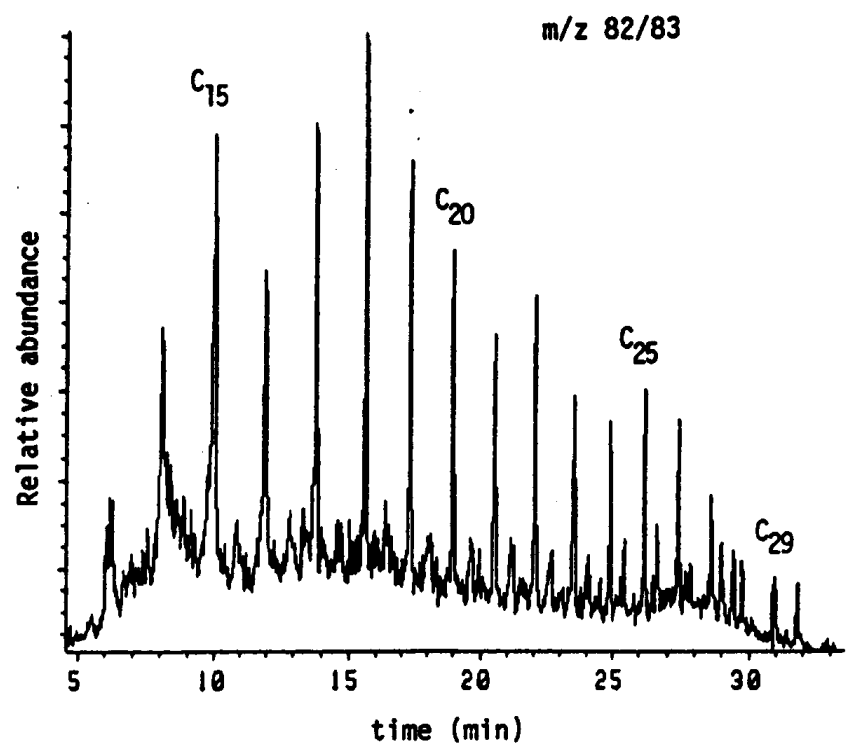

Fig. 4. $m / z$ 82-83 Mass chromatogram showing the distribution of the $n$-alkylcyclohexane series.

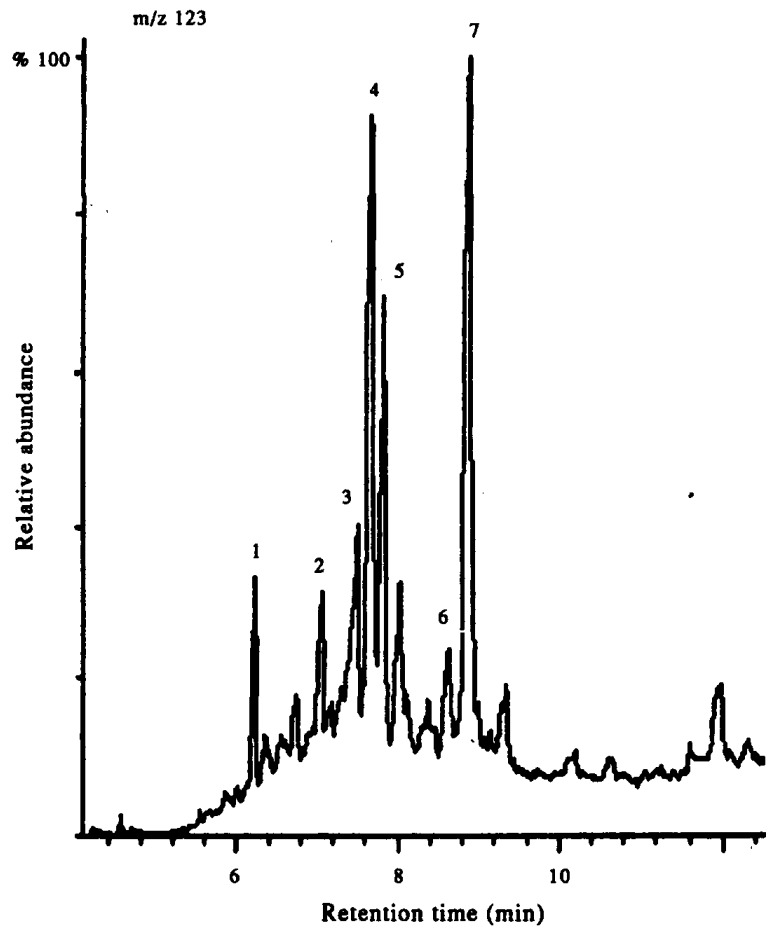

Fig. 5. Partial chromatogram of $m / z 123$ showing the presence of sesquiterpenoid hydrocarbons. For peak assignments refer to Table 3 . 
groups in positions $\mathrm{C}_{21}$ and $\mathrm{C}_{26}$ (Moldowan et al., 1983). The $\mathrm{C}_{26}$ and $\mathrm{C}_{28}$ components were resolved as the $\mathbf{R}$ and $\mathrm{S}$ isomers. Different natural precursors such as tricyclohexaprenol, formed anaerobically from a ubiquitous cell constituent, hexaprenol, have been proposed as likely precursors for this series (Aquino Neto et al., 1983; Moldowan et al., 1983; Ekweozor and Strausz, 1983; Cyr and Strausz, 1983).

Two compounds with a molecular ion at $m / z 330$ and prominent fragments at $m / z 191$ were identified as $\mathrm{C}_{24}$ tetracyclanes (Fig. 6). According to their mass spectra, relative retention times and the assignments made by Aquino Neto et al. (1983) and Czochanska et al. (1988), the compound eluting between the $C_{24}$ and $\mathrm{C}_{25}$ tricyclic terpanes was tentatively identified as a des-A triterpenoid hydrocarbon derived from either an oleanane (VIII, $\mathrm{R} 1=\mathrm{H}, \mathrm{R} 2=\mathrm{CH}_{3}$ ) or ursane (VIII, $\mathrm{R} 1=\mathrm{CH}_{3}, \mathrm{R} 2=\mathrm{H}$ ) skeleton. This compound is a degradation product of higher plant triterpenoids with oxygenated functional groups at the C-3 position of the skeleton e.g. $\alpha$ - and $\beta$-amyrin). The second compound has a retention time between the $\mathrm{C}_{25}$ and $\mathrm{C}_{26}$ tricyclic terpanes and corresponds to $\mathrm{a}_{24}$ 17(21)-secohopane (IX). The tetracyclic terpanes with a 17(21)-secohopane skeleton are usually present in the $\mathrm{C}_{24}-\mathrm{C}_{27}$ range. (Aquino Neto et al., 1983). The transformation of hopanoids into tetracyclic compounds is thought to occur by cleavage of the 17(21) bond of the pentacyclic hopanoids (see Fig. 7) either by microbial activity, during early diagenesis, or by thermocatalytic degradation (Trendel et al., 1982).
The presence of the $\mathrm{C}_{24}$ tetracyclanes has been reported previously in relatively high abundance in coals, and oils derived mainly from terrigenous source materials. In the POS, the high abundance of the $\dot{C}_{24}$ tetracyclanes, relative to the tricyclic terpanes, can be considered as an indication of a significant input of higher plant material (Trendel et al., 1982).

A complex mixture of 8,14-secohopanes (X) was also detected in trace amounts in the saturated fraction of the POS. Due to the complexity, the series was analyzed by GC-MS/MS of the characteristic fragment ion $\mathrm{m} / z 123$ and the corresponding molecular ions at $m / z 372+14 n$ as shown in Fig. 8. The series was detected in the $\mathrm{C}_{27}-\mathrm{C}_{32}$ range, with the exception of the $\mathrm{C}_{28}$ homolog. Two stereoisomers ( $S$ and $R$ ) were detected for the $\mathrm{C}_{31}$ and $\mathrm{C}_{32}$ homologs. The presence of different isomers for each carbon number was also confirmed, although the assignment of their stereochemistry was not possible. 8(14)-secohopanes derive directly from hopanes by ring- $\mathrm{C}$ opening and might be the precursors of the series of bicyclic sesquiterpenoids with the drimane skeleton, discussed previously, by further cleavage of the $11(12)$ bond (Alexander et al., 1984; Hussler et al., 1984a), as shown in Fig. 7.

Ring-D aromatized 8,14-secohopanes (XI) have also been identified by monitoring the ion at $m / z 365$ as shown in Fig. 9. This series of compounds was found in the $\mathrm{C}_{29}-\mathrm{C}_{32}$ range and was dominated by the $\mathrm{C}_{29}$ homolog, as observed in other sediments (Hussler et al., 1984b; Connan et al., 1986). It has been

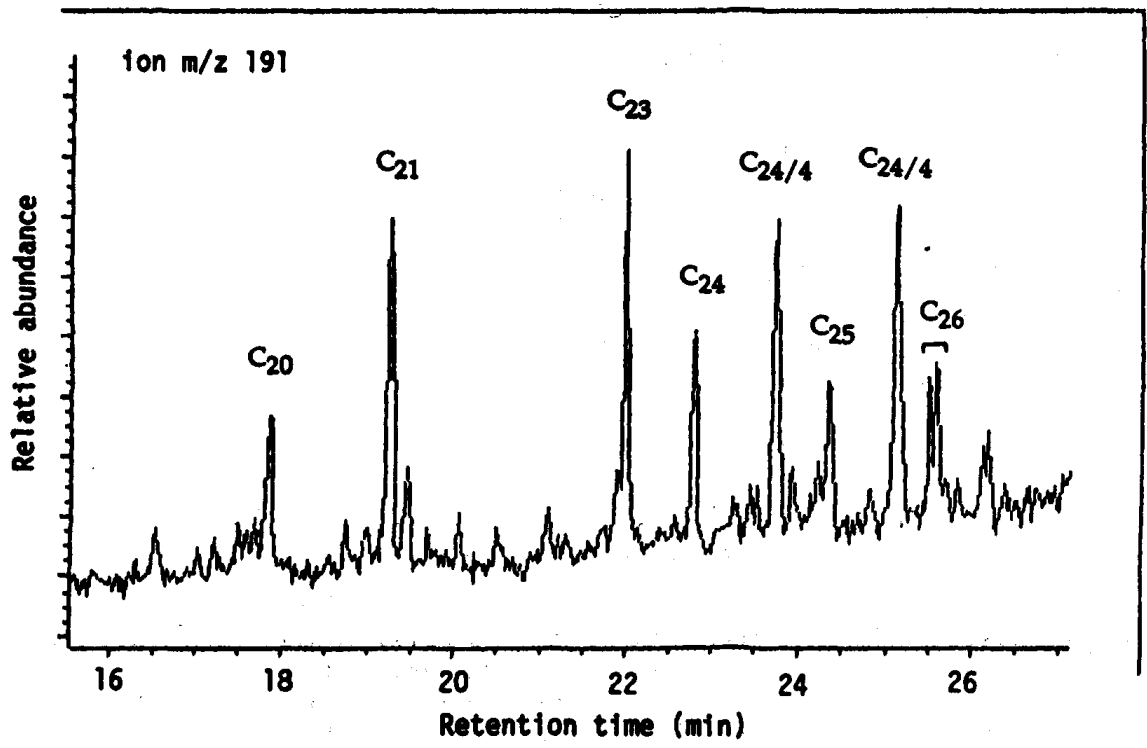

Fig. 6. Partial chromatogram of the ion at $m / z 191$ showing the tricyclic and tetracyclic terpenoid hydrocarbons. 


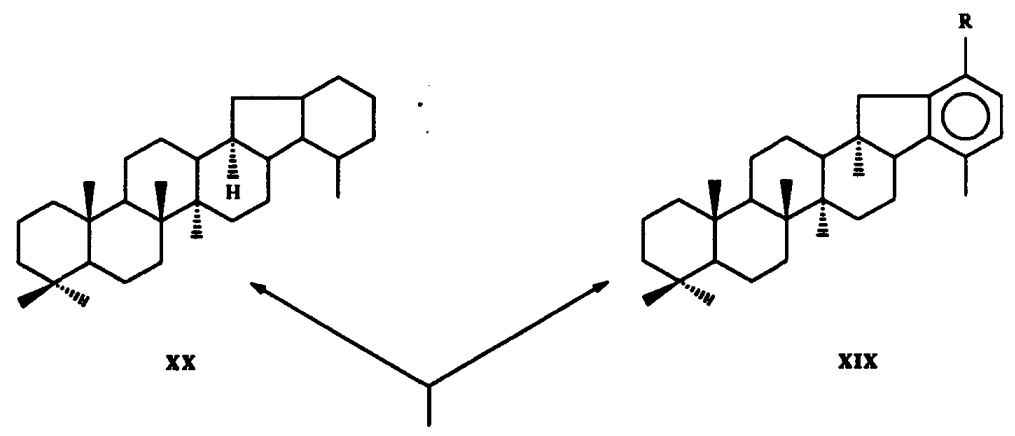<smiles>CC(CCC(O)C(O)C(O)CO)[C@H]1CC2C[C@]3(C)C[C@]21CC[C@]1(C)C3CCC2[C@]1(C)CCC1C(C)(C)CCC[C@]12C</smiles>

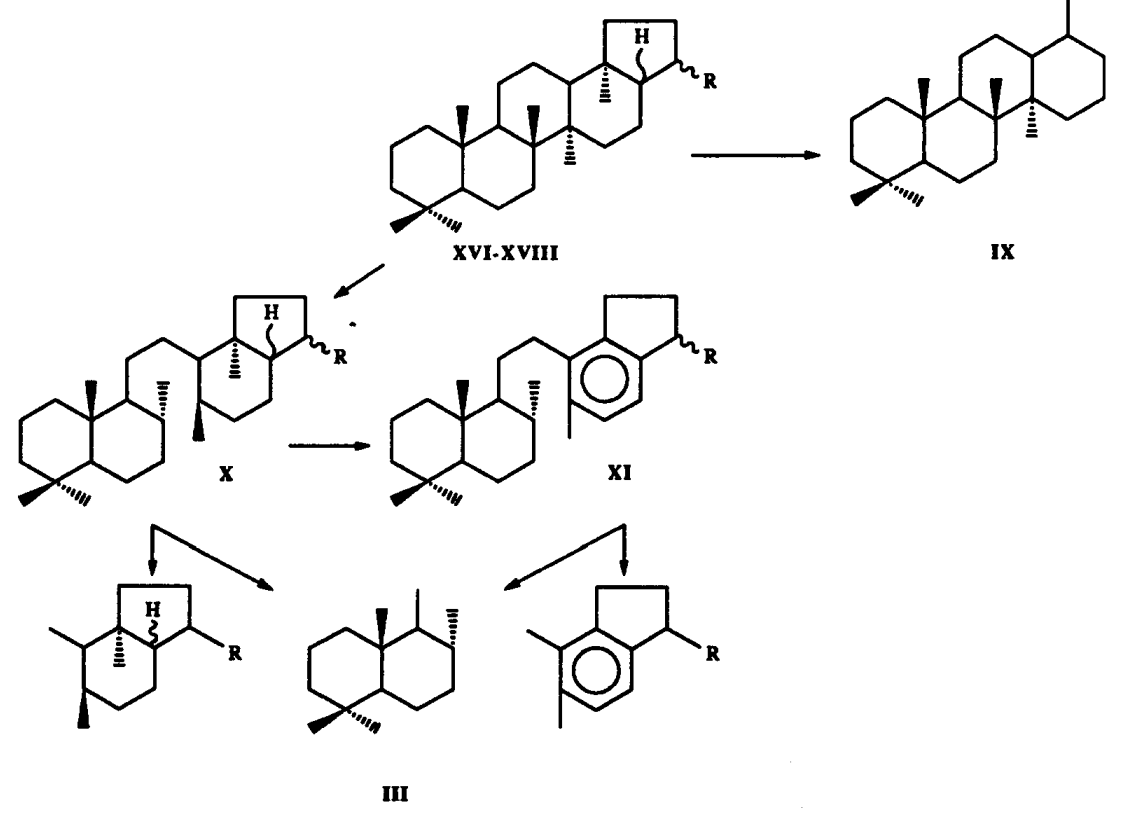

Fig. 7. Probable diagenetic pathway for the hopanoid compounds present in the Puertollano oil shale. Roman numbers refer to the structures showed in the Appendix.

proposed that this series is formed as consequence of thermal alteration of hopanoid precursors (Rinaldi et al., 1988). These types of compounds have been detected in immature oil shales (Hussler et al., 1981) and have been considered to indicate evaporitecarbonate environments. The monoaromatic secohopanes are formed by ring-C opening of a hopane precursor and subsequent aromatization (see Fig. 7).

The distribution of the penta- and hexacyclic hopanoid hydrocarbons $\left(\mathrm{C}_{27}-\mathrm{C}_{35}\right)(\mathbf{X V I}-\mathrm{XX})$ detected in the POS is shown in the $m / z 191$ mass fragmentogram (Fig. 10). Table 4 lists the identities of the individual components, according to previously reported mass spectra and relative retention times (Seifert and 
Moldowan, 1978; Philp, 1985). The ubiquitous presence of hopanes in geological samples has been related to bacterial activity, and a contribution of green-blue algae (Ourisson et al., 1979). In the POS extracts they consist mainly of the $22 S$ and $22 R$ $17 \alpha(\mathrm{H}), 21 \beta(\mathrm{H})$-hopanes at equilibrium concentrations for the extended homologues. The most abundant components are $17 \alpha(\mathrm{H}), 21 \beta(\mathrm{H})$-trisnorhopane (Tm) (B, XVII $\mathrm{R}=\mathrm{H}), \quad 17 \alpha(\mathrm{H}), 21 \beta(\mathrm{H})$ norhopane (C, XVII, $\mathrm{R}=\mathrm{C}_{2} \mathrm{H}_{5}$ ) and $17 \alpha(\mathrm{H}), 21 \beta(\mathrm{H})$ hopane (E, XVII, $\left.\mathrm{R}=i-\mathrm{C}_{3} \mathrm{H}_{7}\right)$. The series of $17 \beta(\mathrm{H}), 21 \alpha(\mathrm{H})$-moretanes (XVIII) is also present in lower proportion. The abundance of the $C_{29}$ and $C_{30}$ primary triterpanes, relative to the other members of the series, suggests that the oil shale has a low maturity level. The ratio of $\mathrm{C}_{30} 17 \beta(\mathrm{H}), 21 \alpha(\mathrm{H})$-more- tane to $17 \alpha(\mathrm{H}), 21 \beta(\mathrm{H})$-hopane has also been used as parameter for maturity level, and its value in the Puertollano oil shale $(0.37)$ also suggests that this sample has not attained maturity. The predominance of $\mathrm{Tm}$ over $\mathrm{Ts}$ also might indicate a moderate maturity level for this sample.

A series of compounds with molecular weights 432 , 446,460 and 474 and a base peak at $m / z 191$ was also observed in the partial chromatogram of the ion $\mathrm{m} / \mathrm{z}$ 191 (Fig. 10). These compounds corresponds to a series of benzohopanes (XIX) ranging from $\mathrm{C}_{32}$ to $\mathrm{C}_{35}$ and previously reported by Hussler et al. (1984b) and Rinaldi et al. (1988). Hussler et al. (1984b) suggested that benzohopanes derive from bacteriohopanetetrol by dehydration and cyclization during very early diagenesis. Subsequent degradation of the side chain

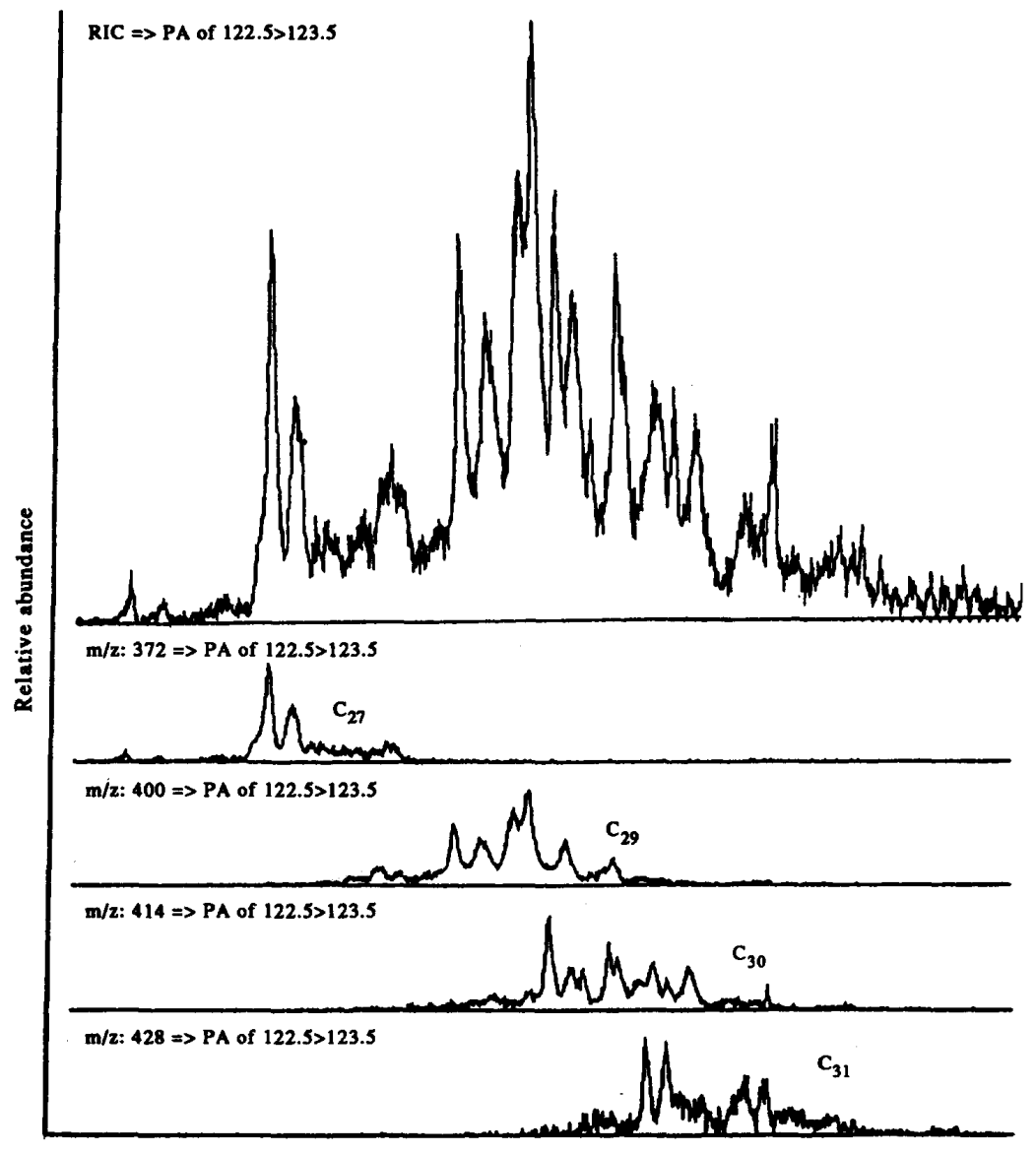

Retention time (min)

Fig. 8. Chromatograms of GC-MS/MS in parent mode (daughter ion at $m / z$ 123) showing 8,14-secohopane distribution (parent ions at $m / z 372,400,414$ and 428). 


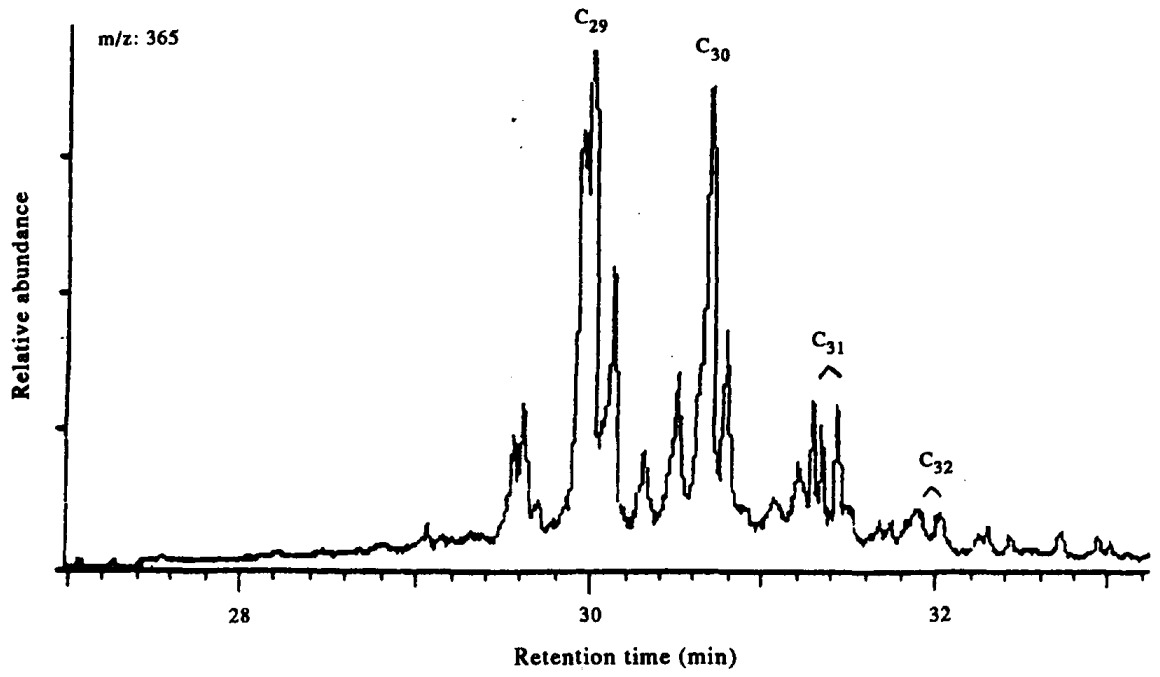

Fig. 9. Partial mass chromatogram of the ion at $m / z 365$ showing the ring-D monoaromatic 8,14 -secohopane distribution.

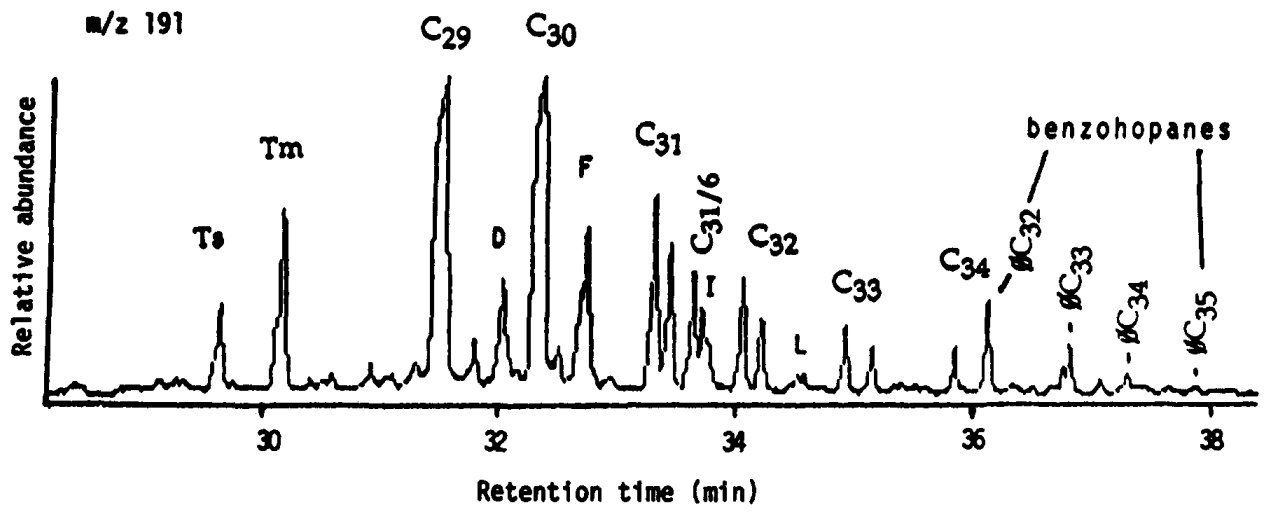

Fig. 10. Mass chromatogram of the ion at $m / z 191$ showing the penta- and hexacyclic triterpenoid distribution. $C_{29}-C_{34}$ refer to the $17 \alpha, 21 \beta$ isomers; capital letters refer to the $17 \beta, 21 \alpha$ isomers listed in Table 4. $\mathrm{C}_{31 / 6}$ is an hexacyclic hopanoid. $\phi_{32}-\phi \mathrm{C}_{35}$ are the benzohopanes.

would lead to the formation of the lower homologs. On the other hand, Rinaldi et al. (1988) postulated biological oxidation before the degradation reaction to explain the formation of the lower members of the

Table 3. Peak identifications for the $m / z 123$ mass chromatogram in

\begin{tabular}{cccc}
\multicolumn{4}{c}{ Fig. 5 } \\
\hline Peak No. & Identity & Formula & Structure \\
\hline 1 & Nordrimane & $\mathrm{C}_{14} \mathrm{H}_{26}$ & \\
2 & Eudesmane & $\mathrm{C}_{15} \mathrm{H}_{28}$ & IV \\
3 & Rearranged drimane & $\mathrm{C}_{15} \mathrm{H}_{28}$ & \\
4 & $8 \beta$-Drimane & $\mathrm{C}_{15} \mathrm{H}_{28}$ & III R $=\mathrm{CH}_{3}$ \\
5 & Desmethyl homodrimane & $\mathrm{C}_{15} \mathrm{H}_{28}$ & \\
6 & Isomer of homodrimane & $\mathrm{C}_{16} \mathrm{H}_{30}$ & \\
7 & $8 \beta$-Homodrimane & $\mathrm{C}_{16} \mathrm{H}_{39}$ & III R $=\mathrm{C}_{2} \mathrm{H}_{3}$ \\
\hline
\end{tabular}

series. Aromatization might be carried out by bacterial oxidation under anaerobic conditions.

A compound with a retention time between the $\mathrm{C}_{31}$ and $\mathrm{C}_{32} \quad 17 \alpha$-hopanes, and a mass spectrum with a base peak at $m / z 191$ and molecular ion at $m / z 424$, was also detected. Its mass spectrum was similar to that reported by Rinaldi et al. (1988) and Connan and Dessort (1987) for a $C_{31}$ hexacyclic hopane $\left(\mathrm{C}_{31 / 6}\right)$, the $18 \alpha(\mathrm{H})$-hexacyclic hopane $(\mathrm{XX})$. This compound is thought to be formed by cyclization of bacterihopanetetrol during the very early diagenetic process (see Fig. 7). The hexacyclic hopanoid series reported by Connan and Dessort (1987) in the $\mathrm{C}_{32}-\mathrm{C}_{35}$ range was not detected in this oil shale, 


\begin{tabular}{|c|c|c|}
\hline Compound & $\begin{array}{c}\text { Elemental } \\
\text { composition }\end{array}$ & Structure \\
\hline $\begin{array}{l}\text { A } 18 \alpha(\mathrm{H})-22,29,30 \text {-trisnorneohopane (Ts) } \\
\text { B } 17 \alpha(\mathrm{H})-22,29,30 \text {-trisnorhopane (Tm) } \\
\text { C } 17 \alpha(\mathrm{H}), 21 \beta(\mathrm{H}) \text {-30-norhopane } \\
\text { D } 17 \beta(\mathrm{H}), 21 \alpha(\mathrm{H}) \text {-30-norhopane } \\
\text { E } 17 \alpha(\mathrm{H}), 21 \beta(\mathrm{H}) \text {-hopane } \\
\text { F } 17 \beta(\mathrm{H}), 21 \alpha(\mathrm{H}) \text {-hopane } \\
\text { G } 17 \alpha(\mathrm{H}), 21 \beta(\mathrm{H}) \text {-homohopane }(22 S) \\
\text { H } 17 \alpha(\mathrm{H}), 21 \beta(\mathrm{H}) \text {-homohopane }(22 R) \\
\text { I } 17 \beta(\mathrm{H}), 21 \alpha(\mathrm{H}) \text {-homohopane } \\
\text { J } 17 \alpha(\mathrm{H}), 21 \beta(\mathrm{H}) \text {-bishomohopane }(22 S) \\
\text { K } 17 \alpha(\mathrm{H}), 21 \beta(\mathrm{H}) \text {-bishomohopane }(22 R) \\
\text { L } 17 \beta(\mathrm{H}), 21 \alpha(\mathrm{H}) \text {-bishomohopane }\end{array}$ & $\begin{array}{l}\mathrm{C}_{27} \mathrm{H}_{46} \\
\mathrm{C}_{27} \mathrm{H}_{46} \\
\mathrm{C}_{29} \mathrm{H}_{50} \\
\mathrm{C}_{29} \mathrm{H}_{50} \\
\mathrm{C}_{30} \mathrm{H}_{52} \\
\mathrm{C}_{30} \mathrm{H}_{52} \\
\mathrm{C}_{31} \mathrm{H}_{54} \\
\mathrm{C}_{31} \mathrm{H}_{54} \\
\mathrm{C}_{31} \mathrm{H}_{54} \\
\mathrm{C}_{32} \mathrm{H}_{56} \\
\mathrm{C}_{32} \mathrm{H}_{56} \\
\mathrm{C}_{32} \mathrm{H}_{56}\end{array}$ & $\begin{aligned} \text { XVI } \\
\text { XVII, } R=\mathbf{H} \\
\text { XVII, } \mathbf{R}=\mathrm{C}_{2} \mathrm{H}_{5} \\
\text { XVIII, } \mathrm{R}=\mathrm{C}_{2} \mathrm{H}_{5} \\
\text { XVII, } \mathrm{R}=i-\mathrm{C}_{3} \mathrm{H}_{7} \\
\text { XVIII, } \mathrm{R}=i-\mathrm{C}_{3} \mathrm{H}_{7} \\
\text { XVII, } \mathrm{R}=\mathrm{s}-\mathrm{C}_{4} \mathrm{H}_{9} \\
\text { XVII, } \mathrm{R}=\mathrm{s}-\mathrm{C}_{4} \mathrm{H}_{9} \\
\text { XVIII, } \mathrm{R}=\mathrm{s}-\mathrm{C}_{4} \mathrm{H}_{9} \\
\text { XVII, } \mathrm{R}=\mathrm{s}-\mathrm{C}_{5} \mathrm{H}_{11} \\
\text { XVII, } \mathrm{R}=\mathrm{s}-\mathrm{C}_{5} \mathrm{H}_{11} \\
\text { XVIII, } \mathrm{R}=\mathrm{s}-\mathrm{C}_{5} \mathrm{C}_{11}\end{aligned}$ \\
\hline
\end{tabular}



$R I C \Rightarrow P A$ of $216.6>217.6$
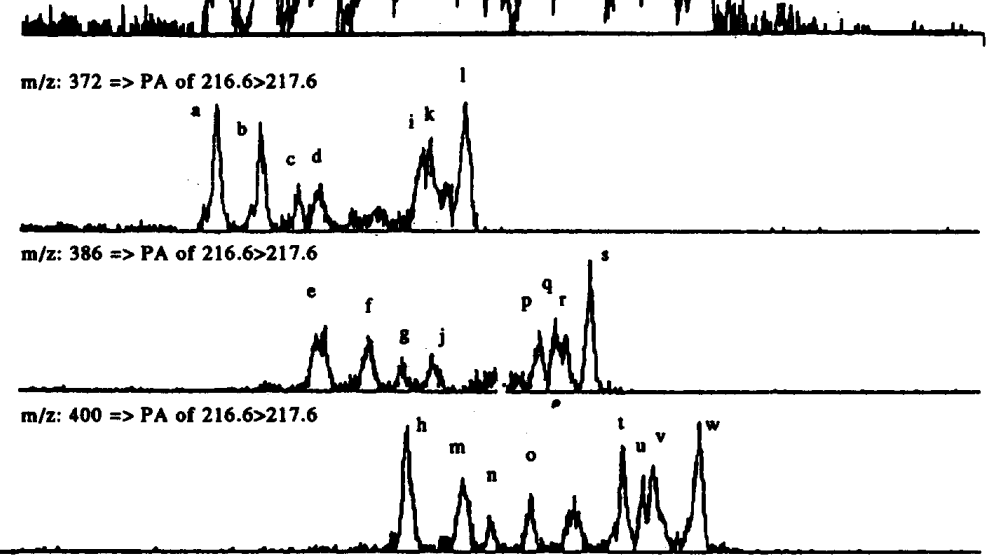

Retention time (min)

Fig. 11. Chromatograms of GC-MS/MS in parent mode (daughter ion at $\mathrm{m} / z$ 217) showing distributions of $C_{27}, C_{28}$ and $C_{29}$ steranes (parent ions at $m / z 372,386,400$ ). For peak assignments refer to Table 4.

suggesting that it has a different diagenetic route of formation than this $\mathrm{C}_{31 / 6}$ compound.

The distribution of steranes in the saturated fraction of the POS consists of a complex mixture of regular and rearranged steranes in the $\mathrm{C}_{27}-\mathrm{C}_{29}$ range and of which many coelute. In order to resolve this complex mixture, the steranes were analyzed by GC-MS/MS. The distribution of sterane parent ions $(m / z 372,386$ and 400) of the daughter ion at $m / z 217$ for the Puertollano oil shale is given in Fig. 11, 


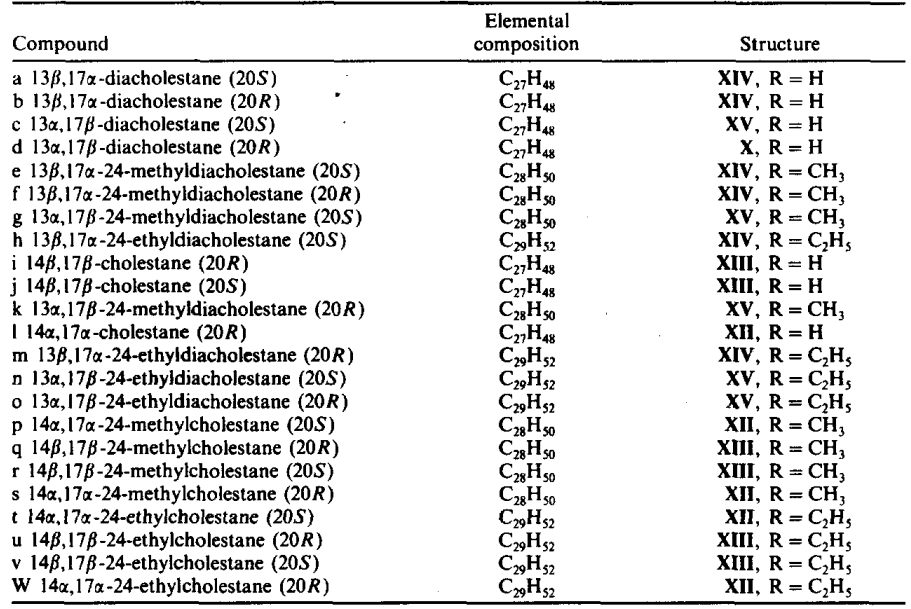

showing the total distribution of $\mathrm{C}_{27}-\mathrm{C}_{29}$ steranes. The identities of the individual components are presented in Table 5. The data show a similar abundance of $\mathrm{C}_{27}$ (XII, $\mathrm{R}=\mathrm{H}$ ), (XII, $\mathrm{R}=\mathrm{CH}_{3}$ ) and $\mathrm{C}_{29}$ (XII, $\mathrm{R}=\mathrm{C}_{2} \mathrm{H}_{5}$ ) pseudohomologues. The $5 \alpha(\mathrm{H}), 14 \alpha(\mathrm{H}), 17 \alpha(\mathrm{H})$ isomers (XII) predominated over the $5 \alpha(\mathrm{H}), 14 \beta(\mathrm{H}), 17 \beta(\mathrm{H})$ isomers (XIII), and a high abundance of diasteranes (XIV, XV) was also apparent. A 4-methyl $C_{30}$ sterane appeared to be present by monitoring the parent/daughter ions at $m / z 414$ and 231 , although no definite structure could be assigned for this compound. The predominance of the biologically occurring $\alpha \alpha R$ isomers over the maturation induced $\beta \beta$ isomers is an indication of the low maturity level of this oil shale, and also of the absence of biodegradation (Philp, 1986).

\section{CONCLUSIONS}

The hydrocarbon distribution in the Puertollano oil shale is dominated by $n$-alkanes, $n$-alkylcyclohexanes, $n$-alkylmethylcyclohexanes and mid-chain monomethyl alkanes. Triterpenoid distributions in the hydrocarbon fraction of the Puertollano oil shale showed a major contribution of bacterially derived hopanoids. The compounds identified comprised the $\mathrm{C}_{27}-\mathrm{C}_{35}$ hopanes (no $\mathrm{C}_{28}$ ), $\mathrm{C}_{27}-\mathrm{C}_{32}$ 8,14-secohopanes, $C_{29}-C_{32}$ ring- $D$ aromatized 8,14-secohopanes, $C_{32}-C_{35}$ benzohopanes and a $C_{31}$ hexacyclic saturated hopane. The gymnosperm and angiosperm derived material is evident in two different groups of diagenetic compounds. Diterpenoids compounds such as abietane, norabietane, simonellite, retene and the sesquiterpenoid cadalene are characteristics of the conifer resins, whereas the terpanes with oleanane and ursane skeleton are characteristics of angiosperms. It is concluded from the results that the Puertollano oil shale has: been formed in a lacustrine environment with significant input of higher plant derived organic materials.

Associate Editor-B. R. T. SIMONEIT

Acknowledgements - The authors wish to thank the DGICyT (PB87-0277) for financial support and Professor R. P. Philp (School of Geology and Geophysics, University of Oklahoma) for the GC-MS/MS facilities.

\section{REFERENCES}

Alexander R., Kagi R. I., Noble R. and Volkman J. K. (1984) Identification of some bicyclic alkanes in petroleum. In Advances in Organic Geochemistry 1983 (Edited by Schenck P. A., de Leeuw J. W. and Lijmbach G. W. M.). Org. Geochem. 6, 63-70. Pergamon Press, Oxford.

Aquino Neto F. R., Trendel J. M., Connan J. and Albrecht P. (1983) Occurrence and formation of tricyclic and tetracyclic terpanes in sediments and oils. In Advances in Organic Geochemistry 1981 (Edited by Bjorøy M. et al.), pp. 659-667. Wiley, Chichester.

Blanco C. G., Prado J. G., Guillén M. D. and Borrego A. G. (1992) Preliminary results of extraction experiments in an oil shale. Org. Geochem. 18, 313-316.

Borrego A. G., Blanco C. G., Prado J. G. and Guillén M. D. (1992) Identification and determination of the different types of hydrogen and carbon atoms in the soluble organic matter of the Puertollano oil shale. Org. Geochem. $18,155-160$.

Connan J. and Dessort D. (1987) Novel family of hexacyclic hopanoid alkanes $\left(\mathrm{C}_{32}-\mathrm{C}_{35}\right)$ occurring in sediments and oils from anoxic paleoenvironments. Org. Geochem. 11, 103-113.

Connan J., Bouroullec J., Dessort D. and Albrecht P. (1986) The microbial input in the carbonate-anhydrite facies of a sabkha paleoenvironment from Guatemala: a molecular approach. Org. Geochem. 10, 29-50.

Cyr T. D. and Strausz O. P. (1983) The structures of tricyclic terpenoid carboxylic acids and their parent alkanes in the Alberta oil sands, Chem. Commun. 1028-1030.

Czochanska Z., Gilbert T. D., Philp R. P., Sheppard C. M., Weston R. J., Wood T. A. and Woolhouse 
A. D. (1988) Geochemical application of sterane and triterpane biomarkers to a description of oils from the Taranaki Basin in New Zealand. Org. Geochem. 12, 123-135.

Ekweozor C. M. and Strausz O. P. (1983) Tricyclic terpanes in the Athabasca oil sands: their geochemistry. In $A d$ vances in Organic Geochemistry 1981 (Edited by Bjorøy M. et al.), pp. 746-768. Wiley, Chichester.

Forey P. L. and Young V. T. (1985) Upper Stephanian fishes from the Puertollano Basin, Ciudad Real, Spain. In Papers on the Carboniferous of the Iberian Peninsula (Sedimentology, Stratigraphy, Paleontology, Tectonics and Geochronology) (Edited by Lemos de Sousa M. J. and Wagner R. H.). An. Fac. Ciênc., Porto Suppl. 64, 137-169.

Fowler M. G., Abolins P. and Douglas A. G. (1986) Monocyclic alkanes in Ordovician organic matter. In Advances in Organic Geochemistry 1985 (Edited by Leythaeuser D. and Rullkötter J.). Org. Geochem. 10, 815-823. Pergamon Press, Oxford.

Hussler G., Chappe B., Wehrung P. and Albrecht P. (1981) $\mathrm{C}_{27}-\mathrm{C}_{29}$ ring $\mathrm{A}$ monoaromatic anthrasteroids in Cretaceous Black Shales. Nature 294, 1179-1182.

Hussler G., Connan J. and Albrecht P. (1984a) Novel families of tetra and hexacyclic aromatic hopanoids predominant in carbonate rocks and crude oils. In Advances in Organic Geochemistry 1983 (Edited by Schenck P. A., de Leeuw J. W. and Lijmbach G. W. M.). Org. Geochem. 6, 39-49. Pergamon Press, Oxford.

Hussler G., Albrecht P., Ourisson G., Cesario M., Guilhem J. and Pascard C. (1984b) Benzohopanes, a novel family of hexacyclic geomarkers in sediments and petroleums. Tetrahedron Lett. 25, 1179-1182.

Kruge M. A. and Suarez-Ruiz I. (1991) Organic geochemistry and petrography of Spanish oil shales. Fuel 70, 1298-1302.

Martín F., García-Mollá J., del Río J. C., Verdejo T. and González-Vila F. J. (1991) Structural features of geolipids and kerogen isolated from a Spanish oil shale. In Organic Geochemistry. Advances and Applications in the Natural Environment (Edited by Manning D. A. C.), pp. 440-443. Manchester University Press, Manchester.

Moldowan J. M., Seifert W. K. and Gallegos E. J. (1983) Identification of an extended series of tricyclic terpanes in petroleum. Geochim. Cosmochim. Acta 47, 1531-1534.

Ourisson G., Albrecht P. and Rohmer M. (1979) The hopanoids. Paleochemistry of a group of natural products. Pure Appl. Chem. 51, 709-729.

Philp R. P. (1985) Fossil Fuel Biomarkers-Applications and Spectra. Elsevier, Amsterdam.

Philp R. P. and Gilbert T. D. (1986a) Biomarker distribution in Australian oils predominantly from terrigenous source material. In Advances in Organic Geochemistry (Edited by Leythaeuser D. and Rullkötter J.). Org. Geochem. 10, 73-84. Pergamon Press, Oxford.
Philp R. D. and Gilbert T. D. (1986b) The detection and identification of biological markers by computerized gas chromatography-mass spectrometry. In Biological Markers in the Sedimentary Record (Edited by Johns R. B.), pp. 227-248. Elsevier, Amsterdam.

Rinaldi G. G. L., Leopold V. M. and Koons C. B. (1988) Presence of benzohopanes, monoaromatic secohopanes and saturated hexacyclic hydrocarbons in petroleum from carbonate environments. In Biochemical Biomarkers (Edited by Yen T. F. and Moldowan M.), pp. 331-353. Harwood Academic.

del Río J. C., García-Mollá J., González-Vila F. J. and Martin F. (1993) Polycyclic aromatic hydrocarbons in fossil fuel extracts. I. The Puertollano oil shale. In Polycyclic Aromatic Hydrocarbons. Synthesis, Properties, Analytical Measurements, Occurrence and Biological Effects (Edited by Garrigues Ph. and Lamotte M.), pp. 621-628. Gordon \& Breach, Ann Arbor, Mich.

Robinson W. E. (1969) Isolation procedure for kerogen and associated soluble organic materials. In Organic Geochemistry. Methods and Results (Edited by Eglinton G. and Murphy M. T. J.), pp. 181-195. Springer, Berlin.

Robinson W. E. and Dineen G. V. (1967) Constitutional aspects of oil shale kerogen. Proc. VII World Petroleum Congress, pp. 669-680.

Rubinstein I. and Strausz O. P. (1979) Geochemistry of the thiourea adduct fraction from an Alberta petroleum. Geochim. Cosmochim. Acta 43, 1387-1392.

Seifert W. K. and Moldowan J. M. (1978) Application of steranes, terpanes and monoaromatics to the maturation, migration and source of crude oils. Geochim. Cosmochim. Acta 42, 77-95.

Simoneit B. R. T. (1978) The organic chemistry of marine sediments. In Chemical Oceanography (Edited by Riley J. P. and Chester R.), 2nd edition, Vol. 7, Chap. 39, pp. 233-311. Academic Press, New York.

Simoneit B. R. T. (1986) Cyclic terpenoids in the geosphere. In Biological Markers in the Sedimentary Record (Edited by Johns R. B.), pp. 43-99. Elsevier Science, Amsterdam.

Trendel J. M., Restle A., Connan J. and Albrecht P. (1982) Identification of a novel series of tetracyclic terpane hydrocarbons (C24-C27) in sediments and petroleums. J. Chem. Soc. Chem. Commun. 304-306.

Wagner R. H. (1985) Upper Stephanian stratigraphy and paleontology of the Puertollano Basin, Ciudad Real, Spain. In Papers on the Carboniferous of the Iberian Peninsula (Sedimentology, Stratigraphy, Palaeontology, Tectonics and Geochronology (Edited by Lemos de Sousa and Wagner R. H. An. Fac. Ciênc., Porto Suppl., 64, 171-231.

Weston R. J., Philp R. P., Sheppard C. M. and Woolhouse A. D. (1989) Sesquiterpanes, diterpanes and other higher terpanes in oils from the Taranaki Basin of New Zealand. Org. Geochem. 14, 405-421. 


\section{APPENDIX}

Structures Cited in Text

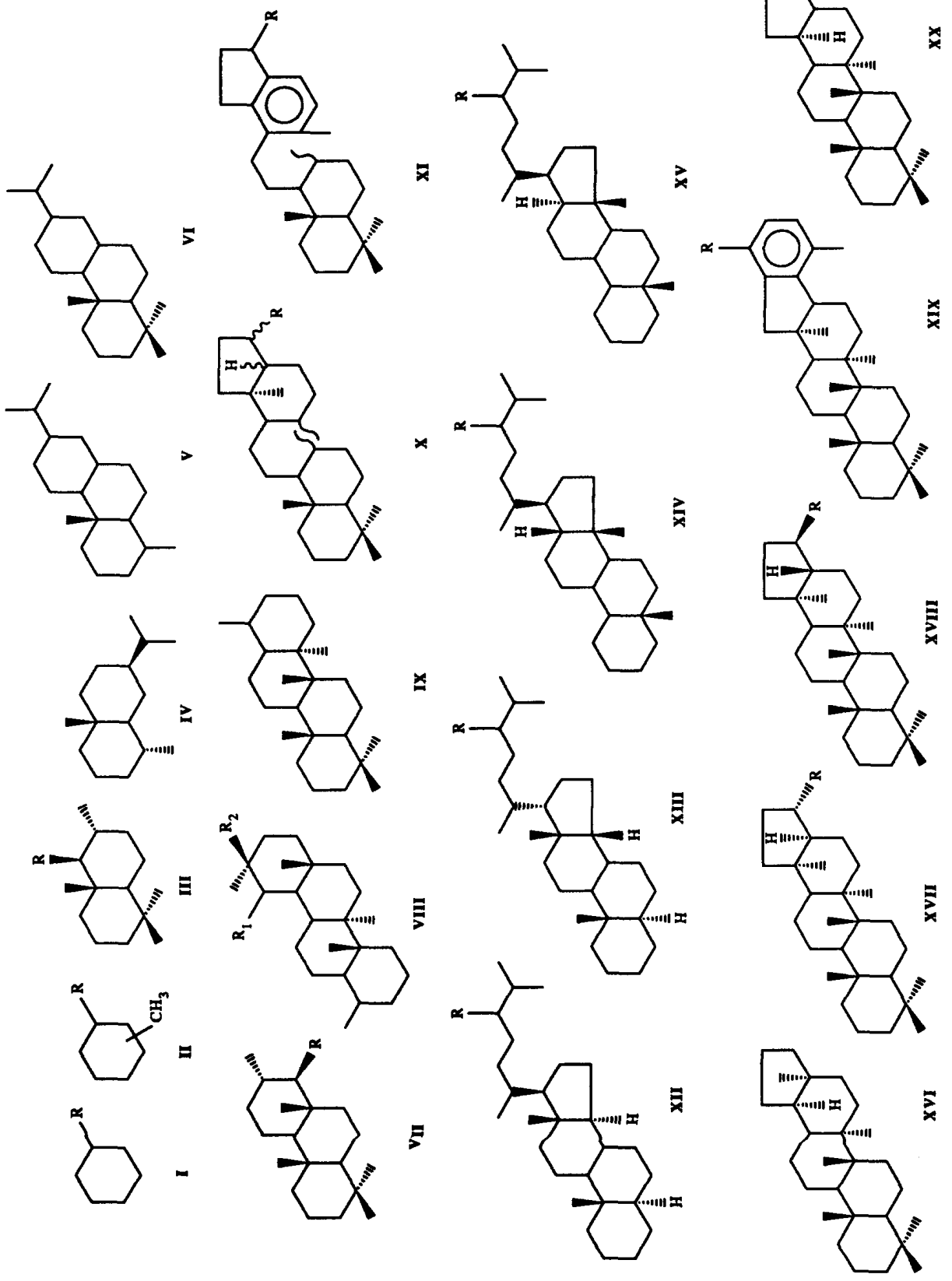

